\title{
Inhibition of 'Zenith' Zoysiagrass Seedling Emergence and Growth by Perennial Ryegrass Leaves and Roots
}

\author{
Alan J. Zuk and Jack D. Fry ${ }^{1}$ \\ Department of Horticulture, Forestry, and Recreation Resources, Kansas State \\ University, Manhattan, KS 66506-5506
}

Additional index words. allelochemical, glyphosate, Lolium perenne, phenolic acid, Zoysia japonica

\begin{abstract}
Establishment of seeded 'Zenith' zoysiagrass (Zoysia japonica Steud.) in an existing sward of perennial ryegrass (Lolium perenne $\mathrm{L}$.) is difficult, and chemicals arising from perennial ryegrass leaf and root tissue may contribute to establishment failure. Experiments were done to evaluate zoysiagrass emergence and growth in soil amended with perennial ryegrass leaves or roots, or after irrigation with water in which perennial ryegrass leaves or roots had previously been soaked. Compared to unamended soil, soil amended with perennial ryegrass leaves at $12 \%$ and $23 \%$ by weight reduced zoysiagrass seedling number $20 \%$ and $26 \%$, respectively; root area and mass were reduced $50 \%$ when amendments comprised $12 \%$ of soil weight. Similar reductions in zoysiagrass seedling emergence and growth were observed in a second soil amendment study, regardless of whether perennial ryegrass was treated with glyphosate or not. Soil mixed with perennial ryegrass leaves, but not roots, at $12 \%$ by weight had a high soil conductivity $\left(5.1 \mathrm{dS} \cdot \mathrm{m}^{-1}\right)$, which could have contributed to reduced zoysiagrass emergence and growth. More than $50 \%$ fewer zoysiagrass seedlings emerged and root mass was up to $65 \%$ lower when irrigated with water in which perennial ryegrass leaves or roots at 5,10 , or $20 \mathrm{~g} \cdot \mathrm{L}^{-1}$ were previously soaked for $\mathbf{4 8}$ hours. Zoysiagrass leaf area, and root length and area, were also lower when irrigated with water previously containing perennial ryegrass roots. Perennial ryegrass leaves and roots have the capacity to inhibit emergence and growth of 'Zenith' zoysiagrass seedlings, which could negatively affect stand establishment.
\end{abstract}

Many golf course superintendents are interested in converting perennial ryegrass fairways to warm-season turfgrasses to reduce costs associated with pest management and irrigation. Zoysiagrass is a popular choice to replace perennial ryegrass because of lower water and fertilizer requirements and the recent release of several cold-hardy seeded cultivars.

Several factors may inhibit germination and establishment of seeded zoysiagrass in an existing perennial ryegrass sward, including competition for resources, alteration of environmental conditions, and potential allelopathic effects of perennial ryegrass on zoysiagrass seedlings. An untreated $1.4-\mathrm{cm}-$ tall perennial ryegrass canopy reduces solar radiation at the soil surface by $72 \%$, a level of shade which was shown to severely inhibit zoysiagrass seedling numbers and shoot and root development in bare-soil plots without perennial ryegrass (Zuk et al., 2005). The only measurable zoysiagrass coverage was achieved in the perennial ryegrass plots that

Received for publication 19 Dec. 2005. Accepted for publication $25 \mathrm{Jan}$. 2006. Publication no. 06-181-J of the Kansas Agricultural Experiment Station. Thanks are extended to the Golf Course Superintendents Association of America, the Kansas Golf Course Superintendents Association, and the Kansas Turfgrass Foundation for supporting this project. We also thank Patten Seed Company, Lakeland, Georgia, for providing seed.

${ }^{1}$ To whom reprint requests should be address; e-mail jfry@ksu.edu. were scalped for the first several weeks after seeding, or in those that were treated with glyphosate [N-(phosphonomethyl)glycine] prior to seeding (Monsanto Inc., St. Louis, Mo.). Despite successful zoysiagrass establishment in glyphosate-treated perennial ryegrass, only $13 \%$ of zoysiagrass pure live seed resulted in seedlings seven weeks after planting (Zuk and Fry, 2005). It is likely that decaying perennial ryegrass leaves on the soil surface reduced seed-to-soil contact and germination, but perennial ryegrass may also have an allelopathic effect on zoysiagrass germination and growth in glyphosate-treated and nontreated swards.

Allelopathy was first reported over 2000 years ago (Inderjit et al., 1995) and is defined as any direct or indirect harmful effect by one plant on another through the production of chemical compounds that escape into the environment (Rice, 1974). Perennial ryegrass has allelopathic effects on alfalfa (Medicago sativa L.) (Chung and Miller, 1995), nodding thistle (Carduus nutans L.) (Nicholson et al., 1990), white clover (Trifolium repens L.) (Prestidge et al., 1992), and lettuce (Lactuca sativa L.) (Buta et al.,1987). Several hundred allelopathic agents have been identified from many chemical classes and it is unlikely that they have a common mode of action (Einhellig, 1995). Rao and Buta (1983) listed 19 phenolic compounds extracted from 'Citation' perennial ryegrass that had an allelopathic effect on 'Grand Rapids' lettuce seed germination. The most common and widely distributed phenolic compounds are the derivatives of cinnamic and benzoic acids, coumarins, tannins, polyphenolic complexes, and certain flavonoids (Einhellig, 2004), and include lignin, anthocyanin and tannins (Ribereau-Gayon, 1968; Walker, 1975). The concentration of phenolic compounds in the soil environment ultimately determines whether there is an allelopathic influence on surrounding plants (Rice, 1984).

The extent to which perennial ryegrass may invoke an allelopathic, inhibitory effect on zoysiagrass seedlings has never been measured. However, unequivocally proving allelopathy is taking place would require identification and extraction of allelochemicals from perennial ryegrass and reapplication in some form to zoysiagrass seedlings. That was beyond the scope of this experiment. For this reason, and because inorganic salts arising from perennial ryegrass plant tissue may also reduce zoysiagrass seedling growth, we choose to use the term growth inhibition rather than allelopathy. The objective of this study was to evaluate the potential for perennial ryegrass leaves and roots to inhibit emergence and growth of 'Zenith' zoysiagrass seedlings.

\section{Materials and Methods}

Soil amendment studies. Zoysiagrass germination and growth were evaluated after seeding into potting soil mixed with leaves or roots from glyphosate-treated (GT) (GT treatment will be described in more detail below) and untreated perennial ryegrass. Potting soil was comprised of $85 \%$ sphagnum peatmoss and $15 \%$ perlite. Fresh perennial ryegrass leaf or root tissue was incorporated into the surface $2.5 \mathrm{~cm}$ at $0 \%, 2 \%, 12 \%$, or $23 \%$ of soil weight. In total, $66 \mathrm{~g}$ of potting soil were mixed with perennial ryegrass plant tissue to produce the $2.5 \mathrm{~cm}$ deep amended soil layer. The mixture of potting soil and perennial ryegrass tissue was then placed in pots measuring $10 \mathrm{~cm}$ long $\times 10 \mathrm{~cm}$ wide $\times 9 \mathrm{~cm}$ deep containing $87 \mathrm{~g}$ of potting soil that was not amended with perennial ryegrass leaf or root tissue in the bottom $6.5 \mathrm{~cm}$ of each pot. For comparative purposes, the percentage of soil volume occupied by perennial ryegrass roots in the field was determined by sampling four 10 -cm-diameter $\times 2.5$-cm-deep cores from a 1.4-cm-tall sward, and soaking the base of each core in water for $24 \mathrm{~h}$. After soaking, soil was washed from roots, and roots were dried in a convection oven at $65{ }^{\circ} \mathrm{C}$ for $48 \mathrm{~h}$ and then weighed.

In Experiment I, perennial ryegrass used in soil amendments was harvested from a blend of equal parts 'Roadrunner', 'Manhattan 3', 'Charger II', and 'Catalina' that was seeded at $292 \mathrm{~kg} \cdot \mathrm{ha}^{-1}$ in flats measuring $52-\mathrm{cm}$ long $\times$ 26 -cm wide $\times 6.5$-cm deep containing calcined clay. Perennial ryegrass was mowed weekly with electric hand-held clippers at a $5-\mathrm{cm}$ height. Flats were watered daily with $1.3 \mathrm{~cm}$ of water. Perennial ryegrass in flats was irrigated once each week with water injected with a water-soluble fertilizer $20 \mathrm{~N}-1.8 \mathrm{P}-14.1 \mathrm{~K}$ to provide a total $350 \mathrm{mg} \mathrm{N}$. The turf grew in the greenhouse for 1 year before harvest and over 
this period received $\mathrm{N}$ at about $600 \mathrm{~kg} \cdot \mathrm{ha}^{-1}$.

Perennial ryegrass used in GT soil amendments was treated with glyphosate at $3.4 \mathrm{~kg} \cdot \mathrm{ha}^{-1}$ with a single-nozzle backpack sprayer $26 \mathrm{~d}$ before harvest. At the time of harvest of GT and nontreated perennial ryegrass, calcined clay was gently washed from the roots. Leaves and roots were cut to $1-\mathrm{cm}$-long pieces, placed in a bowl, and mixed with potting soil as previously described.

On 3 Mar. 2001, twenty 'Zenith' zoysiagrass seeds [ $85 \%$ pure live seed (PLS)] were placed onto the soil surface in each pot and then moved to a growth chamber set at $30 / 25^{\circ} \mathrm{C}$ (day/night) with a $16-\mathrm{h}$ photoperiod $\left(356 \mu \mathrm{mol} \cdot \mathrm{m}^{-2} \cdot \mathrm{s}^{-1}\right)$ for $30 \mathrm{~d}$. Pots were watered twice daily with distilled water to provide a total of $5 \mathrm{~mm} \cdot \mathrm{d}^{-1}$. After removal from the growth chamber on 3 Apr. 2001, pots were placed in a cooler at 3.9 ${ }^{\circ} \mathrm{C}$ until harvest a few days later.

Experiment II was conducted from 15 Aug. to 15 Sept. 2001 using the same methods described for Experiment I. Perennial ryegrass was maintained in the greenhouse for 18 months before harvesting, using the same cultural practices as described in Experiment I. During that time, it received a total of about $900 \mathrm{~kg} \mathrm{~N} / \mathrm{ha}$ from the same soluble fertilizer described in Amendment Experiment I.

After each study was concluded, zoysiagrass plants in each pot were harvested, and data were collected on seedling number, tiller number, leaf area and mass, and root length, area, and mass. Seedling and tiller numbers in each experimental unit were counted. Leaf and root area, and root length, were measured using a Panasonic WV-CD20 camera and AgVision rootmeasurement software(Decagon Devices, Inc., Pullman, Wash.). Before scanning, all roots were dipped in methyl blue $\left(5 \mathrm{~g} \cdot \mathrm{L}^{-1} \mathrm{H}_{2} \mathrm{O}\right)$ to facilitate root measurement. Roots were placed in a transparent scanning tray containing water to facilitate root separation. After scanning, leaf and root biomass were determined by drying the plant tissue in a convection oven at $65^{\circ} \mathrm{C}$ for $48 \mathrm{~h}$ and then weighing.

Both experimental designs were a 2 (root or leaf amendment $) \times 2($ GT or untreated $) \times$ $3(2 \%, 12 \%$, or $23 \%$ by weight $)$ factorial plus a control in a completely randomized design with four replications. Results between studies were variable and are therefore presented separately. Data were analyzed in two steps using the Statistical Analysis Systems (SAS, 2000) general linear model (GLM) procedure. First, pairwise comparisons against the control were performed for each treatment combina- tion using $t$ tests. Then the analysis of variance (ANOVA) procedure was used to test for effects of soil amendments and levels in the 2 $\times 2 \times 3$ factorial. Means were separated using $\mathrm{F}$ protected LSD tests.

Perennial ryegrass irrigation solution experiments. Zoysiagrass germination and growth were evaluated when irrigated using distilled water in which perennial ryegrass leaves or roots had been soaked for $48 \mathrm{~h}$. In Experiment I, a blend of perennial ryegrass composed of equal parts 'Brightstar II', 'Manhattan 3' and 'Catalina' was seeded on 5 August 2003 at $341 \mathrm{~kg} \cdot \mathrm{ha}^{-1}$ in flats containing sand, and of the same dimensions used in the soil amendment studies. Perennial ryegrass turf was managed for 2 to 5 months as previously described for the soil amendment studies and received $\mathrm{N}$ at about $50 \mathrm{~kg} \cdot \mathrm{ha}^{-1} \cdot \mathrm{month}^{-1}$.

Perennial ryegrass leaves and roots were harvested on 31 Oct. and 11 and 24 Nov. 2003 to prepare irrigation solutions. Sand was washed from the roots, and leaves and roots were cut into $1-\mathrm{cm}$ long sections. Leaves or roots from perennial ryegrass were then added to distilled water in twelve 3.8-L plastic containers to provide tissue at 5,10 or $20 \mathrm{~g} \cdot \mathrm{L}^{-1}$. Another portion of leaf and root segments was weighed first, placed in plastic bags, immersed in liquid $\mathrm{N}$ for $2 \mathrm{~min}$ to kill the tissue at $-196^{\circ} \mathrm{C}$, and then added to distilled water. Immersion in liquid $\mathrm{N}$ was done to fracture cellular membranes and allow more of the allelochemicals to leak from leaf and root tissue.

After $48 \mathrm{~h}$, water in all containers was poured through strainers to remove plant tissue, and recollected to serve as an irrigation solution for zoysiagrass seedlings. Irrigation solutions remained in refrigeration at $5{ }^{\circ} \mathrm{C}$ during the duration of the experiment except when used to water seedlings.

On 5 Nov. 2003, pots measuring 10-cmlong $\times 10$-cm-wide $\times 9$-cm-deep were filled with the potting mixture described in the soil amendment studies, and saturated with 300 $\mathrm{ml}$ of irrigation solution. Twenty 'Zenith' zoysiagrass seeds (39\% PLS) were planted on the surface of the potting soil. The low PLS level was unexpected, but we believed that zoysiagrass emergence and growth observed in untreated pots was satisfactory and the experiment could proceed. Pots were placed in a growth chamber set at $30 / 25^{\circ} \mathrm{C}$ (day/night) with a 16 -h photoperiod $\left(331 \mu \mathrm{mol} \cdot \mathrm{m}^{-2} \cdot \mathrm{s}^{-1}\right)$ for $43 \mathrm{~d}$. Individual pots received $50 \mathrm{ml}$ of irrigation solution daily. Pots were removed from the growth chamber on 17 Dec. 2003 and placed in a refrigerated cooler at $5^{\circ} \mathrm{C}$ until zoysiagrass was harvested several days later.

Irrigation solution Experiment II was conducted by seeding a perennial ryegrass blend containing equal parts 'Charger', 'Manhattan 4 ' and 'Citation Fore' perennial ryegrass at 341 $\mathrm{kg} \cdot \mathrm{ha}^{-1}$ on 5 Dec. 2003. Perennial ryegrass turf was managed for three months as previously described for Solution Experiment I. Perennial ryegrass leaves and roots were harvested beginning on 1 Mar. 2004 to prepare solutions as described in Solution Experiment I. An aliquot of each solution was submitted to the KSU Soil Testing Laboratory for analysis of $\mathrm{N}, \mathrm{P}, \mathrm{pH}$, and conductivity (Table 4).

On 9 Mar. 2004, 20 'Zenith' zoysiagrass seeds $(60 \%$ PLS) were planted on the surface of potting mix (described previously) retained in pots similar to those described for soil amendment studies. Pots in which zoysiagrass was seeded were arranged in a 2 (roots or leaves soaked in water $) \times 3(5,10$, or 20 $\left.\mathrm{g} \cdot \mathrm{L}^{-1}\right) \times 2$ (immersed or not immersed in liquid N) factorial plus a control in a randomized complete block design with four replicates in a growth chamber set at $30 / 25^{\circ} \mathrm{C}$ (day/night) with a $16-\mathrm{h}$ photoperiod $\left(552 \mu \mathrm{mol} \cdot \mathrm{m}^{-2} \cdot \mathrm{s}^{-1}\right)$ for $43 \mathrm{~d}$. Zoysiagrass was watered following the same procedure described for Solution Experiment I. Pots were removed from the growth chamber on $20 \mathrm{Apr}$. 2004 and placed in a cooler at $5^{\circ} \mathrm{C}$ until zoysiagrass seedlings were harvested several days later. Zoysiagrass leaf and root parameters from the irrigation solution studies were measured using an Epson Expression scanner with WIN RHIZO leaf and root scanning software (Regent Instruments, Inc., Quebec). Root tissue was prepared for scanning as described in the soil amendment studies. Data were collected on the same parameters measured in the soil amendment studies. Results from studies were variable; therefore, data are presented and discussed separately for each study. Data were analyzed using the same two-step procedure outlined for the soil amendment studies.

After harvest, soil from the surface $2.5 \mathrm{~cm}$ of each pot was collected and tested for salinity level by the KSU Soil Testing Laboratory.

\section{Results}

Soil amendment experiments. The main effect of perennial ryegrass soil amendment level was significant $(P<0.05)$, but plant part had no effect, nor did whether the perennial ryegrass had been treated with glyphosate before amend-

Table 1. 'Zenith' zoysiagrass germination and growth as affected by soil amendments with perennial ryegrass leaves and roots in soil amendment Experiment I.

\begin{tabular}{|c|c|c|c|c|c|c|c|}
\hline $\begin{array}{l}\text { Level } \\
(\%)^{x}\end{array}$ & $\begin{array}{l}\text { Seedlings } \\
\left(\text { no. } / \mathrm{dm}^{2}\right)\end{array}$ & $\begin{array}{c}\text { Tillers } \\
\left(\text { no. } / \mathrm{dm}^{2}\right)\end{array}$ & $\begin{array}{c}\text { Leaf area } \\
\left(\mathrm{cm}^{2} \cdot \mathrm{dm}^{-2}\right)\end{array}$ & $\begin{array}{l}\text { Leaf wt } \\
\left(\mathrm{g} \cdot \mathrm{m}^{-2}\right)\end{array}$ & $\begin{array}{l}\text { Root length } \\
\left(\mathrm{cm} \cdot \mathrm{cm}^{-3}\right)\end{array}$ & $\begin{array}{l}\text { Root area } \\
\left(\mathrm{cm}^{2} \cdot \mathrm{cm}^{-3}\right)\end{array}$ & $\begin{array}{c}\text { Root wt } \\
\left(\mathrm{mg}^{\circ} \mathrm{cm}^{-3}\right)\end{array}$ \\
\hline 2 & $11.9 \mathrm{a}$ & $35.8 \mathrm{a}$ & $30 \mathrm{a}$ & $15.4 \mathrm{a}$ & $0.39 \mathrm{a}$ & $0.05 \mathrm{a}$ & $0.05 \mathrm{a}$ \\
\hline
\end{tabular}

${ }^{2}$ Twenty 'Zenith' zoysiagrass seeds were placed in each pot on 3 Mar. 2001. Pots were immediately placed in a growth chamber set at $30 / 25{ }^{\circ} \mathrm{C}(\mathrm{day} / \mathrm{night}) \mathrm{with}$ a 16-h photoperiod $\left(356 \mu \mathrm{mol} \cdot \mathrm{m}^{-2} \cdot \mathrm{s}^{-1}\right)$ for $30 \mathrm{~d}$ before harvest on $3 \mathrm{Apr}$. Seedlings were watered twice daily with distilled water to provide a total of $5 \mathrm{~mm} \cdot \mathrm{d}^{-1}$. ${ }^{y}$ Means within a column followed by the same letter are not significantly different $(P \leq 0.05)$. Numbers represent the mean of four observations in the control, and 16 observations at $2 \%, 12 \%$, and $23 \%$ [main effect averaged over two types of tissue (leaves and roots) and two glyphosate treatment levels (treated and nontreated)]

${ }^{x}$ Level of soil amendment is a percent of soil dry weight in the surface $2.5 \mathrm{~cm}$. 
ing the soil. Therefore, zoysiagrass seedling growth responses to leaves and roots are averaged over amendment levels and glyphosate treatment. Compared to unamended soil, soil amended with perennial ryegrass reduced zoysiagrass seedling and tiller numbers at the $12 \%$ and $23 \%$ soil amendment levels, and leaf and root area and mass at $12 \%$ (Table 1).

In Amendment Experiment II, a significant $(P<0.05)$ plant part $\times$ type $\times$ level interaction was observed for all root parameters. Furthermore, planned contrasts with data from zoysiagrass growing in unamended soil indicated significant differences with many of the shoot parameters evaluated. Zoysiagrass seedlings growing in soil amended with either non-GT or GT-perennial ryegrass exhibited reduced shoot and root growth (Table 2). Greatest reduction in zoysiagrass seedling shoot and root parameters was observed in soil amended with nontreated or GT perennial ryegrass leaves. At the end of the study, salinity evaluation of the top $2.5 \mathrm{~cm}$ of soil amended with perennial ryegrass plant parts at $12 \%$ by weight indicated a low (1.4 $\mathrm{dS} \cdot \mathrm{m}^{-1}$ ) conductivity level in soil amended with roots, moderate $\left(2.5 \mathrm{dS} \cdot \mathrm{m}^{-1}\right)$ level in nonamended soil, and high $\left(5.1 \mathrm{dS} \cdot \mathrm{m}^{-1}\right)$ level in soil amended with leaves.

Perennial ryegrass irrigation solution Studies. Perennial ryegrass plant part had a significant $(P<0.05)$ effect on zoysiagrass leaf area and inclusion of the control in contrasts revealed additional differences in Solution Experiment I. Therefore, plant part main effects were averaged over levels and liquid $\mathrm{N}$ treatment. Zoysiagrass seedling emergence was reduced by $53 \%$ when irrigated with water in which leaves had been soaked and $60 \%$ in water which had contained roots (Table 3 ). Furthermore, root mass was reduced by $57 \%$ and $66 \%$, respectively, when irrigated with water which contained leaves or roots (Table 3). Zoysiagrass leaf area, and root length and area, were also $32 \%$ to $48 \%$ lower when irrigated with water in which perennial ryegrass roots had been present.

In solution Experiment II, the main effect of plant part was significant $(P<0.05)$. The perennial ryegrass root irrigation solution significantly reduced zoysiagrass root mass $\left(0.15 \mathrm{mg} \cdot \mathrm{cm}^{-3}\right)$ relative to the control $(0.3$ $\left.\mathrm{mg} \cdot \mathrm{cm}^{-3}\right)$.

Nitrogen levels in irrigation solutions in which perennial ryegrass leaves or roots were soaked fell within a normal range with the exception of solutions in which leaves were included at $20 \mathrm{~g} \cdot \mathrm{L}^{-1}$ (high $\mathrm{N}$ level) and liquid-N treated leaves at $10 \mathrm{~g} \cdot \mathrm{L}^{-1}($ high $\mathrm{N}$ level) and $20 \mathrm{~g} \cdot \mathrm{L}^{-1}$ (very high $\mathrm{N}$ level) (Table 4). All solutions had high or very high $P$ levels. Tests indicated that $\mathrm{pH}$ was relatively normal in irrigation solutions across all leaf and root levels, with the exception of that prepared using leaves at $20 \mathrm{~g} \cdot \mathrm{L}^{-1}$ immersed in liquid $\mathrm{N}$, which had a $\mathrm{pH}$ of 5.1. Conductivity of all solutions was low, as was the soil conductivity at the end of the study.

\section{Discussion}

We provide evidence that zoysiagrass seedlings are affected by growth inhibitory effects of perennial ryegrass leaves and roots. Such effects may include allelopathy, the presence of inorganic salts, or another unidentified mechanism(s). Zoysiagrass growth suppression resulting from the presence of perennial ryegrass leaves or roots in soil or irrigation water was sometimes greater when higher levels of tissue were used, but the response was variable. For example, in Soil Amendment Experiment I, zoysiagrass leaf area was lower than the control when soil was amended with $12 \%$ perennial ryegrass leaves, but was similar to the control when amended at $23 \%$.

In soil amendment Experiment II, perennial ryegrass leaves and roots, whether previously treated with glyphosate or not, inhibited seedling zoysiagrass shoot or root development at levels as low as $2 \%$ by weight of the root zone's surface $2.5 \mathrm{~cm}$ (Table 2). Seedling zoysiagrass at the base of the perennial ryegrass canopy would be growing in soil composed of $>10 \%$ roots by weight to $2.5-\mathrm{cm}$ depth as determined by sampling of field cores.

Perennial ryegrass clippings resulting from frequent mowing filter to the base of the canopy and occupy the same surrounds as emerging zoysiagrass seedlings. Perennial ryegrass leaves inhibited zoysiagrass seedling emergence and growth when included as an amendment in a potting soil mixture, or when irrigation water where leaves had previously been soaked was used to irrigate seedlings. This inhibitory effect may be caused by allelochemicals, such as phenolic acids leaking from severed and decaying perennial ryegrass leaves. Allelopathic potential of other plants has been reported to be greater when plant residues are left on the soil surface (Guenzi et al., 1967; Martin and Smith, 1994; Smith,

Table 2. 'Zenith' zoysiagrass germination and growth as affected by soil amendment with perennial ryegrass leaves or roots, glyphosate treatment, and soil amendment level in soil amendment Experiment II. ${ }^{\mathrm{z}}$

\begin{tabular}{|c|c|c|c|c|c|c|c|c|c|}
\hline Part & Type & $\begin{array}{c}\text { Level } \\
(\%)^{\mathrm{x}}\end{array}$ & $\begin{array}{l}\text { Seedlings } \\
\left(\text { no. } / \mathrm{dm}^{2}\right)\end{array}$ & $\begin{array}{c}\text { Tillers } \\
\left(\text { no. } / \mathrm{dm}^{2}\right)\end{array}$ & $\begin{array}{c}\text { Leaf area } \\
\left(\mathrm{cm}^{2} \cdot \mathrm{dm}^{-2}\right)\end{array}$ & $\begin{array}{l}\text { Leaf wt } \\
\left(\mathrm{g} \cdot \mathrm{m}^{-2}\right)\end{array}$ & $\begin{array}{l}\text { Root length } \\
\left(\mathrm{cm} \cdot \mathrm{cm}^{-3}\right)\end{array}$ & $\begin{array}{l}\text { Root area } \\
\left(\mathrm{cm}^{2} \cdot \mathrm{cm}^{-3}\right)\end{array}$ & $\begin{array}{c}\text { Root wt } \\
\left(\mathrm{mg} \cdot \mathrm{cm}^{-3}\right)\end{array}$ \\
\hline Control & -- & --- & $15.8 \mathrm{ab}^{\mathrm{y}}$ & $44.8 \mathrm{a}$ & $46 \mathrm{a}$ & $16.0 \mathrm{a}$ & $0.29 \mathrm{~b}$ & $0.020 \mathrm{a}$ & $0.0300 \mathrm{~b}$ \\
\hline Leaf & $\mathrm{GT}^{\mathrm{w}}$ & 2 & $12.8 \mathrm{abc}$ & $26.5 \mathrm{~cd}$ & 13 cde & 4.0 cde & 0.07 cde & $0.003 \mathrm{~b}$ & $0.0040 \mathrm{c}$ \\
\hline Leaf & GT & 12 & $12.8 \mathrm{abc}$ & $21.0 \mathrm{~cd}$ & $6 \mathrm{de}$ & $2.0 \mathrm{de}$ & 0.04 cde & $0.002 \mathrm{~b}$ & $0.0020 \mathrm{c}$ \\
\hline Leaf & GT & 23 & $8.0 \mathrm{de}$ & $8.3 \mathrm{f}$ & $3 e$ & $0.8 \mathrm{e}$ & $0.03 \mathrm{de}$ & $0.002 \mathrm{~b}$ & $0.0020 \mathrm{c}$ \\
\hline Leaf & Non-GT & 2 & $10.3 \mathrm{~cd}$ & $17.0 \mathrm{def}$ & $11 \mathrm{cde}$ & $5.0 \mathrm{cde}$ & 0.09 cde & $0.004 \mathrm{~b}$ & $0.0060 \mathrm{c}$ \\
\hline Leaf & Non-GT & 12 & $5.0 \mathrm{e}$ & $7.0 \mathrm{f}$ & $2 \mathrm{e}$ & $0.7 \mathrm{e}$ & $0.02 \mathrm{e}$ & $0.001 \mathrm{~b}$ & $0.0007 \mathrm{c}$ \\
\hline Leaf & Non-GT & 23 & $7.8 \mathrm{de}$ & $9.0 \mathrm{ef}$ & $2 \mathrm{e}$ & $0.7 \mathrm{e}$ & $0.02 \mathrm{e}$ & $0.001 \mathrm{~b}$ & $0.0009 \mathrm{c}$ \\
\hline Root & GT & 2 & $17.0 \mathrm{a}$ & $39.3 \mathrm{ab}$ & $32 \mathrm{~b}$ & $13.0 \mathrm{ab}$ & $0.43 \mathrm{a}$ & $0.030 \mathrm{a}$ & $0.0400 \mathrm{a}$ \\
\hline Root & GT & 12 & $12.5 \mathrm{bc}$ & 20.3 cde & $15 \mathrm{~cd}$ & $6.0 \mathrm{~cd}$ & $0.14 \mathrm{c}$ & $0.007 \mathrm{~b}$ & $0.0090 \mathrm{c}$ \\
\hline Root & GT & 23 & $16.3 \mathrm{ab}$ & $29.8 \mathrm{bc}$ & $18 \mathrm{c}$ & $8.1 \mathrm{c}$ & $0.11 \mathrm{cde}$ & $0.006 \mathrm{~b}$ & $0.0070 \mathrm{c}$ \\
\hline Root & Non-GT & 2 & $11.5 \mathrm{~cd}$ & $26.8 \mathrm{~cd}$ & $21 \mathrm{bc}$ & $8.6 \mathrm{bc}$ & $0.13 \mathrm{~cd}$ & $0.007 \mathrm{~b}$ & $0.0090 \mathrm{c}$ \\
\hline Root & Non-GT & 12 & $10.3 \mathrm{~cd}$ & $22.8 \mathrm{~cd}$ & $15 \mathrm{~cd}$ & $6.0 \mathrm{~cd}$ & $0.12 \mathrm{~cd}$ & $0.007 \mathrm{~b}$ & $0.0090 \mathrm{c}$ \\
\hline Root & Non-GT & 23 & $11.0 \mathrm{~cd}$ & $20.8 \mathrm{~cd}$ & 7 cde & $3.0 \mathrm{de}$ & 0.04 cde & $0.004 \mathrm{~b}$ & $0.0030 \mathrm{c}$ \\
\hline
\end{tabular}

zTwenty 'Zenith' zoysiagrass seeds were placed in each pot on $15 \mathrm{Aug}$. 2001 . Pots were immediately placed in a growth chamber set at $30 / 25{ }^{\circ} \mathrm{C}$ (day/night) with a 16-h photoperiod $\left(356 \mu \mathrm{mol} \cdot \mathrm{m}^{-2} \cdot \mathrm{s}^{-1}\right)$ for $30 \mathrm{~d}$ before harvest on $15 \mathrm{Sept}$. Seedlings were watered twice daily with distilled water to provide a total of $5 \mathrm{~mm} \cdot \mathrm{d}^{-1}$. ${ }^{y}$ Means within a column followed by the same letter are not significantly different $(P \leq 0.05)$. Numbers represent the mean of four replications.

${ }^{x}$ Level of soil amendment is a percent of soil dry weight in the upper $2.5 \mathrm{~cm}$ of the rootzone.

${ }^{\mathrm{w}} \mathrm{GT}=$ glyphosate-treated.

Table 3. 'Zenith' zoysiagrass germination and growth as affected by irrigation with water in which perennial ryegrass leaves or roots had previously been soaked in solution Experiment $\mathrm{I}^{\mathrm{z}}$.

\begin{tabular}{|c|c|c|c|c|c|c|c|}
\hline Part & $\begin{array}{l}\text { Seedlings } \\
\left(\text { no. } / \mathrm{dm}^{2}\right)\end{array}$ & $\begin{array}{c}\text { Tillers } \\
\text { (no./dm²) }\end{array}$ & $\begin{array}{l}\text { Leaf area } \\
\left(\mathrm{cm}^{2} \cdot \mathrm{dm}^{-2}\right)\end{array}$ & $\begin{array}{c}\text { Leaf wt } \\
\left(\mathrm{g} \cdot \mathrm{m}^{-2}\right)\end{array}$ & $\begin{array}{l}\text { Root length } \\
\left(\mathrm{cm} \cdot \mathrm{cm}^{-3}\right)\end{array}$ & $\begin{array}{l}\text { Root area } \\
\left(\mathrm{cm}^{2} \cdot \mathrm{cm}^{-3}\right)\end{array}$ & $\begin{array}{c}\text { Root wt } \\
\left(\mathrm{mg} \cdot \mathrm{cm}^{-3}\right)\end{array}$ \\
\hline Control & $7.0 \mathrm{a}^{\mathrm{y}}$ & $42.0 \mathrm{a}$ & $1.74 \mathrm{ab}$ & $62.1 \mathrm{a}$ & $1.70 \mathrm{a}$ & $0.29 \mathrm{a}$ & $0.35 \mathrm{a}$ \\
\hline Leaves & $3.3 \mathrm{~b}$ & $37.1 \mathrm{a}$ & $1.85 \mathrm{a}$ & $48.3 \mathrm{a}$ & $1.16 \mathrm{ab}$ & $0.18 \mathrm{ab}$ & $0.15 \mathrm{~b}$ \\
\hline Roots & $2.8 \mathrm{~b}$ & $29.7 \mathrm{a}$ & $1.19 \mathrm{~b}$ & $35.8 \mathrm{a}$ & $0.95 \mathrm{~b}$ & $0.15 \mathrm{~b}$ & $0.12 \mathrm{~b}$ \\
\hline
\end{tabular}

zTwenty 'Zenith' zoysiagrass seeds were placed in each pot on 5 Nov. 2003. Pots were immediately placed in a growth chamber set at $30 / 25{ }^{\circ} \mathrm{C}$ (day/night) with a 16-h photoperiod $\left(331 \mu \mathrm{mol} \cdot \mathrm{m}^{-2} \cdot \mathrm{s}^{-1}\right)$ for $43 \mathrm{~d}$ before harvest on $17 \mathrm{Dec}$. The pots were initially watered with $300 \mathrm{ml}$ of irrigation solution before seeding to saturate the potting mixture, followed with $50 \mathrm{~mL} \cdot \mathrm{d}^{-1}$.

${ }^{\mathrm{y}}$ Means within a column followed by the same letter are not significantly different $(P \leq 0.05)$. 
Table 4. Total N, P, pH, and conductivity of solutions in which perennial ryegrass leaves or roots had previously been soaked for $48 \mathrm{~h}$ in solution Experiment II.

\begin{tabular}{lcccc}
\hline $\begin{array}{l}\text { Perennial ryegrass } \\
\text { plant part and } \\
\text { concn }\left(\mathrm{mg} \cdot \mathrm{kg}^{-1}\right)\end{array}$ & $\begin{array}{c}\text { Total N } \\
\left(\mathrm{mg} \cdot \mathrm{L}^{-1}\right)^{\mathrm{z}}\end{array}$ & $\begin{array}{c}\text { Total P } \\
\left(\mathrm{mg} \cdot \mathrm{L}^{-1}\right)^{\mathrm{y}}\end{array}$ & $\mathrm{pH}^{\mathrm{x}}$ & $\begin{array}{c}\text { Conductivity } \\
\left(\mathrm{dS} \cdot \mathrm{m}^{-1}\right)^{\mathrm{w}}\end{array}$ \\
\hline Distilled water & 0.1 & 0.1 & 7.0 & 0.003 \\
Leaves (5) & 1.6 & 1.0 & 6.8 & 0.049 \\
LNT $^{\mathrm{v}}$ leaves (5) & 7.9 & 3.5 & 6.4 & 0.106 \\
Roots (5) & 0.3 & 0.3 & 7.0 & 0.019 \\
LNT roots (5) & 1.5 & 0.7 & 6.9 & 0.029 \\
Leaves (10) & 3.6 & 2.0 & 6.6 & 0.104 \\
LNT leaves (10) & 11.6 & 6.2 & 6.4 & 0.207 \\
Roots (10) & 0.8 & 0.5 & 7.0 & 0.030 \\
LNT roots (10) & 2.7 & 1.4 & 6.8 & 0.052 \\
Leaves (20) & 11.5 & 7.0 & 6.5 & 0.345 \\
LNT leaves (20) & 34.3 & 14.5 & 5.1 & 0.476 \\
Roots (20) & 1.2 & 0.9 & 6.6 & 0.050 \\
LNT roots (20) & 4.0 & 2.3 & 6.7 & 0.090 \\
\hline R & & &
\end{tabular}

${ }^{2}$ Rating: $<1.1$ low, 1.1 to 11.3 normal, 11.3 to 22.6 high, and $>22.6$ very high (Harivandi, 1994).

${ }^{y}$ Rating: 0 to 0.1 low, $0.1-0.4$ normal, 0.4 to 0.8 high, and $>0.8$ very high (Harivandi, 1994).

xRating: 6.5 to 7 normal range for irrigation water (Harivandi, 1999).

wRating: $<0.75$ low, 0.75 to 1.5 medium, 1.5 to 3.00 high, and $>3.00$ very high (Harivandi, 1994).

${ }^{\vee} \mathrm{LNT}=$ liquid nitrogen treated. Leaves were soaked for $120 \mathrm{~s}$ in liquid nitrogen before placing in distilled water.

1990; Smith and Martin, 1994; Tukey, 1969). Accumulation of enough perennial ryegrass leaf clippings on the soil surface could also raise salinity in the immediate vicinity of the zoysiagrass seedling to a level that might inhibit growth, as salinity levels in soil amended with $12 \%$ perennial ryegrass leaves was high. As such, there may be inhibitory contributions of inorganic salts, in addition to allelochemicals, on the zoysiagrass seedling. Zoysiagrass has moderate salinity tolerance (Marcum,1999), but seedlings may be more susceptible to saline conditions.

Lickfeldt et al. (2001) found that leaf extracts from perennial ryegrass inhibited germination and root growth of radish (Raphanus sativus L.), annual ryegrass (Lolium multiflorum Lam.), lettuce, large crabgrass (Digitaria sanguinalis (L.) Scop.), and white clover in petri dishes. Wardle et al. (1996) demonstrated that leachates collected from a fine mist of water applied over perennial ryegrass leaves reduced germination and radical growth of musk thistle (Carduus nutans L.).

We also observed inhibition of zoysiagras seedling emergence and shoot and root growth after irrigating with distilled water in which perennial ryegrass leaves or roots were previously soaked. None of the irrigation solutions had a high salinity content, which suggests that allelochemicals were responsible for the reduction in zoysiagrass emergence and growth. Lickfeldt etal. (2001) found that leachates from pots in which perennial ryegrass was growing had no effect on germination or growth of radish when evaluated over a 12 -week period. Contrasting methods used herein compared to those employed by Lickfeldt et al. (2001) may account for differing results. Allelochemicals in the leachates collected by Lickfeldt et al. (2001) would have had to originate from intact roots. Herein, roots were severed before placing in distilled water, which would have resulted in greater leaking of potential allelochemicals.
Nevertheless, during midsummer heat stress, which would coincide with the optimum planting time for seeded zoysiagrass, it is common for perennial ryegrass roots to senesce (Fry and Huang, 2004), and any allelochemicals contained would then leak into the surrounding soil. Neither we, nor Lickfeldt et al. (2001) quanitified levels of allelochemicals in irrigation solutions.

Lickfeldt et al. (2001) concluded that allelopathic effects of turfgrasses on weedy monocots and dicots were unlikely after no effect of soil leachates was observed on radish germination in one experiment, and lack of growth inhibition of crabgrass on soil that had previously supported growth of tall fescue in a second study. Our results indicate that, in addition to being subject to plant competition and reduced light levels at the soil surface (Zuk et al., 2005), 'Zenith' zoysiagrass seedlings in a perennial ryegrass sward are also subject to inhibition resulting from perennial ryegrass leaves and roots.

\section{Literature Cited}

Buta, J.G., D.W. Spaulding, and A.N. Reed. 1987. Differential growth responses of fractionated turfgrass seeds and leachates. HortScience 22:1317-1319.

Chung, I.M. and D.A. Miller. 1995. Allelopathic influences of nine forage grass extracts on germination and seed growth of alfalfa. Agron. J. 87:767-772.

Einhellig, F.A. 1995. Mechanism of action of allelochemicals in allelopathy, p. 96-116. In: Inderjit, K.M.M. Dakshini and F.A. Einhellig (eds.). Allelopathy: Organisms, processes and applications. Amer. Chem. Soc., Wash., D.C.

Einhellig, F.A. 2004. Mode of allelochemical action of phenolic compounds, p. 217-238. In: F.A. Macias, J.C.G. Galindo, J.M.G. Molinillo, and H.G. Cutler (eds.). Allelopathy: Chemistry and mode of action of allelochemicals. CRC Press, Boca Raton, Fla.

Fry, J. and B. Huang. 2004. Applied turfgrass science and physiology. Wiley. Hoboken, N.J.

Guenzi, W.D., T.M. McCalla, and F.A. Norstadt 1967. Presence and persistence of phytotoxic substances in wheat, oat, corn, and sorghum residues. Agron. J. 59:163-166.

Harivandi, M.A. 1999. Interpreting turfgrass irrigation water test results. California turfgrass culture. Calif. Agr. Expt. Sta. Res. Bul. 49(1-4).

Harivandi, M.A. 1994. Wastewater quality and treatment plants, p. 106-129. In: Wastewater reuse for golf course irrigation. Lewis Publ., Ann Arbor, Mich.

Inderjit, K.M.M. Dakshini, and F.A. Einhellig. 1995. Allelopathy: organisms, processes and applications. Amer. Chem. Soc., Wash., D.C.

Lickfeldt, D.W., T.B. Voigt, B.E. Branham, and T.W. Fermanian. 2001. Evaluation of allelopathy in cool season turfgrass species. Intl. Turfgrass Soc. Res. J. 9:1013-1018.

Marcum, K.B. 1999. Salinity tolerance mechanisms of grasses in the subfamily chloridoideae. Crop Sci. 39:1153-1160

Martin, L.D. and A.E. Smith. 1994. Allelopathic potential of some warm-season grasses. Crop Protection 13:388-392.

Nicholson, K.S.,A. Rahman, and D.A. Wardle. 1990. Interactions between establishing nodding thistle and pasture seedlings, p. 225-228. In: Proc. 43rd Weed and Pest Control Conf., Hamilton, New Zealand.

Prestidge, R.A., E.R. Thom, S.L. Marshall, M.J. Taylor, B. Willoughby, and D.D. Wildermoth. 1992. Influence of Acremonum lolii infection in perennial ryegrass on germination, emergence, survival and growth of white clover. N.Z. J. Agr. Res. 35:225-234.

Rice, E.L. 1974. Allelopathy. Academic Press, New York.

Rice, E.L. 1984. Allelopathy. 2nd ed. Academic Press, New York.

Rao, M.M. and G. Buta. 1983. Growth inhibitors from grasses: HPLC of phenolics, p. 43-48. In: Proc. 10th Plant Growth Regulat. Soc. Amer. Conf., Mich. State University, East Lansing.

Ribereau-Gayon, P. 1968. University reviews in botany: Plant phenolics. V.H. Heywood (ed.). Oliver and Boyd, Edinburgh, Scotland.

Smith, A.E. 1990. Potential allelopathic influence of certain pasture weeds. Crop Protection 9:410-414.

Smith,A.E. and L.D. Martin. 1994. Allelopathic characteristics of three cool-season grass species in the forage ecosystem. Agron. J. 86:243-246.

StatisticalAnalysis System. 1999-2000. version 8.1, SAS Inst. Inc., Cary, N.C.

Tukey, H.G. 1969. Implications of allelopathy in agricultural plant science. Bot. Rev. 35:1-16.

Walker, J.R.L. 1975. The institute of biology's studies in biology no. 54: The biology of plant phenolics. Edward Arnold Ltd., London, U.K.

Wardle, D.A., K.S. Nicholson, and A. Rahmen. 1996. Use of a comparative approach to identify allelopathic potential and relationship between allelopathy bioassays and "competition" experiments for ten grassland and plant species. J. Chem. Ecol. 22:933-948.

Zuk, A.J., D. Bremer, and J.D. Fry. 2005. Establishment of seeded zoysiagrass in a perennial ryegrass sward: Effects of soil-surface irradiance and temperature. Intl. Turfgrass Soc. Res. J. 10:302-309.

Zuk, A.J. and J.D. Fry. 2005. Seeded zoysiagrass establishment in a perennial ryegrass sward. Crop Sci. 45:1521-1528. 